\title{
Profil Cemaran Bakteri Coliform pada Minuman Susu Segar yang Dijual Pedagang Kaki Lima di Daerah Istimewa Yogyakarta
}

\author{
Profile of Coliform Bacteria Contamination in Fresh Milk at the Sidewalk Trader in \\ Yogyakarta Province
}

\author{
Charis Amarantini $^{*}$, Tri Yahya Budiarso ${ }^{1}$, Regina Suryanto ${ }^{1}$ \\ Fakultas Biologi-Universitas Kristen Duta Wacana, Yogyakarta \\ Telp. (0274) 563929 Fax. : (0274) 513235 \\ e-mail: charis@ukdw.ac.id/yahya@ukdw.ac.id*Penulisuntuk korespondensi
}

\begin{abstract}
Coliform contamination emerges public health case particularly by pathogenic E.coli 0157 which is characterized by hemorrhagic colitis with diarrhea. In order to study the profile of coliform bacteria contamination in fresh milk that was sold by the sidewalk trader in Yogyakarta province, in this research coliform detection was done by cultivate fresh milk samples on the medium of Chromocult Coliform Agar (CCA) and enrichment cultures on the medium of Vancomycin-Trypticase Soy Broth (mVTSB). Dark-blue colonies isolated on CCA plates were then evaluated for the ability to ferment D-sorbitol on EOH medium in order to suspect pathogenic E.coli 0157 colonies. The results show that coliform contamination was $1.10^{3}-1.10^{7} \mathrm{CFU} / \mathrm{ml}$, although it was not detected on all of the samples. Profile of coliform contamination in fresh milk samples consisted of Citrobacter, Enterobacter, and Klebsiella $\left(1,0.10^{3}-1,2.10^{7} \mathrm{CFU} / \mathrm{ml}\right)$, Shigella, Salmonella, and Yersinia $\left(1,0.10^{3}-2,1.10^{6} \mathrm{CFU} / \mathrm{ml}\right)$, and E.coli $\left(1,4.10^{4}-2,8.10^{4} \mathrm{CFU} / \mathrm{ml}\right)$. Dark-blue isolates that were suspected as pathogenic E.coli do not ferment D-sorbitol on EOH medium. Based on this result, it was concluded that it was not associated with E.coli 0157.
\end{abstract}

Key words: contamination, coliform, E.coli, fresh milk

Diterima: 03 Maret 2004, disetujui: 06 Mei 2004

\section{Pendahuluan}

Famili Enterobacteriaceae menduduki reputasi tertinggi sebagai bakteri penyebab penyakit yang umumnya berasosiasi dengan jalur intestin. Bakteri coliform merupakan salah satu anggota dari famili Enterobacteriaceae. Bakteri enterik ini berbentuk batang memiliki sifat gram negatif, fakultatif anaerob, dan hidup dalam saluran usus hewan, baik pada hewan yang sehat maupun hewan sakit. Bakteri dalam famili Enterobacteriaceae memiliki arti penting secara medis, karena sebagian genera bersifat patogen pada saluran usus manusia seperti Salmonella, Shigella, dan Yersinia. Beberapa genera lain mampu berkolonisasi sebagai flora normal pada saluran pencernaan manusia, diantaranya Escherichia, Enterobacter, dan Klebsiella, tetapi kelompok bakteri ini juga dapat menyebabkan penyakit (Todar, 1997). Escherichia coli dan Enterobacter aerogenes merupakan bagian terbesar dari kelompok bakteri famili Enterobacteriaceae (Jay, 1978). Escherichia coli secara umum ditemukan di saluran intestin pada manusia ataupun hewan, sehingga digunakan sebagai indikator adanya kontaminasi feses pada lingkungan (Atlas, 1997).

Escherichia coli termasuk dalam famili Enterobacteriacea, merupakan bakteri gram negatip, bersifat motil, memfermentasi laktosa, 
bersifat aerogenik dan menghasilkan gas dan asam dari glukosa (Doyle dan Cliver, 1990). Dinding sel memiliki struktur yang terdiri dari beberapa lapis. Lapisan paling dalam adalah membran plasma, lapisan kedua berupa peptidoglikan, sedang lapisan paling luar adalah lipopolisakharida (LPS) dan protein (Brock, 1999). Fungsi lapisan terluar dinding sel antara lain sebagai penghalang terluar, memiliki sifat toksin dan bertanggungjawab terhadap beberapa gejala infeksi. Escherichia coli memproduksi enterotoksin, yaitu toksin yang dibebaskan ke luar sel. Enterotoksin bekerja pada usus halus, umumnya menyebabkan sekresi cairan yang berlebihan kedalam lumen usus, yang selanjutnya disebut diare. Penyerangan toksin pada usus memerlukan adanya protein permukaan sel bakteri yang menyebabkan kemampuan bakteri untuk menempel pada sel epitelium usus (Brock, 1999).

Ada tiga kelompok utama struktur antigen Enterobacteriaceae yaitu antigen $\mathrm{O}$ (somatik), antigen $\mathrm{H}$ (flagela), dan antigen $\mathrm{K}$ (kapsula). Antigen $\mathrm{O}$ merupakan bagian terluar dinding sel termasuk LPS. Antigen $\mathrm{O}$ bersifat tahan terhadap panas dan alkohol. Escherichia coli memiliki satu atau lebih antigen $\mathrm{O}$. Antigen $\mathrm{O}$ digunakan untuk menggolonggolongkan serotipe, misalnya serotipe O157. Antigen $\mathrm{H}$ terletak pada flagela, dan dapat didenaturasi oleh panas dan alkohol. Antigen K dari E.coli termasuk antigen yang tersusun atas polisakharida. Untuk serotyping E.coli, pada saat ini dikenal lebih dari 171 antigen $\mathrm{O}, 56$ antigen $\mathrm{H}$, dan 90 antigen $\mathrm{K}$ (Doyle dan Cliver, 1990; Atlas, 1997).

Menurut Doyle dan Schoeni (1987), galur E.coli dapat bersifat patogen pada manusia. Organisme ini berpotensi menghasilkan sitotoxin dengan sebutan verositotoxin I dan II. Infeksi $E$ coli patogenik menimbulkan problem serius pada berbagai kasus kesehatan di masyarakat, karena dapat menyebabkan penyakit diare yang terkait dengan terjadinya pendarahan. Escherichia coli mempunyai toxin paling sedikit berjumlah 2 yaitu: (a) Alpha Hemolysin yang menghancurkan sel darah merah dan (b) Enterotoksin yang menyebabkan diare (Jay, 1978; Ray, 1996).
Escherichia coli 0157:H7 merupaka salah satu organisme patogen pada manusia Organisme ini berpotensi menghasilka sitotoksin yang dikenal sebagai Shiga-lik toxin I (SLT-I) dan SLT-II atau lebih dikena dengan sebutan verositotoksin I dan II. Infeks E.coli patogenik menimbulkan problem seriu pada berbagai kasus kesehatan masyaraka karena dapat menyebabkan penyakit diare yan terkait dengan terjadinya pendarahan ata dikenal dengan sebutan hemorrhagic coliti (HC). Kondisi ini jika berlangsung teru menerus dapat menyebabkan penyaki hemolytic uremic syndrome (HUS) microangiopathic hemolytic anemias, ata thrombotic thrombocytopenic purpura (Padh dan Doyle, 1991). Escherichia coli penghasi verositotoksin (VTEC) dapat dijumpai pad kotoran hewan peliharaan dan kebanyaka terdapat pada hewan ruminansia. Penyaki karena HUS juga ditemukan pada anak-ana setelah mengkonsumsi susu segar (Doyle da Schoeni, 1987). Pada tahun 1993 enterohemorrhagic E.coli O157:H7 menjad penyebab lebih dari 500 kasus hemorrhagi colitis dan HUS di Amerika karen mengkonsumsi daging atau hamburger Kontaminasi daging diduga berasal dar kotoran hewan pada saat pemotongan. Selai daging kasus serupa juga terdapat pada ai minum dan susu mentah ataupun susu yan sudah mengalami pasteurisasi. Lebih dari 90\% pasien mengalami sakit karena mengkonsums susu pasteurisasi dalam kemasan karto ataupun botol. Selain Amerika, Canada da Scotlandia juga mengalami kasus serup (Steinhart, et al., 1996). Sumber utam kontaminasi VTEC menurut Borczyk et al (1987) berasal dari saluran pencernaan hewa dan hasil ikutannya sangat potensia menyebabkan infeksi pada manusia. Sus segar, produk keju yang berasal dari sus mentah dan susu pasteurisasi, yan terkontaminasi feses merupakan sumber infeks pula.

Susu mengandung nutrisi yang sanga kompleks, yaitu tersusun atas: air $(87,4 \%)$ laktosa $(4,6 \%)$; protein $(3,2 \%)$; lemak $(3,9 \%$ dan mineral $(0,9 \%)$. Komposisi susu yan demikian merupakan medium yang sangat bai untuk pertumbuhan mikrobia. Susu yan 
dihasilkan dari sapi sehat pada umumnya relatif terbebas dari kontaminasi mikrobia. Jika terjadi kontaminasi bakteri, maka kontaminan pada umumnya berasal dari lingkungan dan peralatan yang dipergunakan selama pemerahan dan jika susu disimpan pada suhu dingin di bawah kondisi yang higienis, maka kontaminasi oleh bakteri sangat rendah, yaitu kurang dari 10.000 bakteri/ml. Jika jumlah bakteri mengalami kenaikan secara signifikan melebihi 3 juta/ml maka akan terjadi degradasi lemak, protein, atau laktosa sehingga menyebabkan bau (Jay, 1978; Harding, 1999). Kontaminasi bakteri coli pada susu yang dihasilkan dari pemerahan pada umumnya berasal dari luar, seperti keadaan lingkungan yang tidak memadai (Adnan, 1984).

Minuman susu segar rentan terkontaminasi oleh bakteri coliform. Kontaminasi disebabkan oleh lamanya proses transportasi mulai dari pemerahan pada pagi hari di tingkat peternak sampai ke tangan pedagang kaki lima sore hari. Walaupun penyimpanan susu sudah dilengkapi dengan tangki pendinginan diperkirakan selama masa penyimpanan mulai dari pemerahan sampai konsumsi mengalami masa inkubasi sekitar 10 jam (Budiarso dan Amarantini, 2002). Pada pedagang kaki lima diduga resiko kontaminasi bertambah oleh sebab pencucian gelas yang tidak bersih, penggunaan kain lap kotor, ataupun proses pemasakan yang tidak sempurna.

Berdasarkan latar belakang tersebut, penelitian ini dilakukan untuk mengkaji profil cemaran bakteri coliform dan mendeteksi keberadaan E.coli O157 patogenik yang mencemari minuman susu segar yang dijual oleh pedagang kaki lima di Daerah Istimewa Yogyakarta. Profil coliform dipetakan berdasarkan pola distribusi warna koloni yang tumbuh pada medium Chromocult Coliform Agar (CCA) (Turner, et al., 2000). Sedangkan keberadaan E.coli patogenik dideteksi berdasarkan pengujian kemampuan menggunakan sorbitol sebagai salah satu penanda karakter fisiologis untuk kelompok E.coli $\mathrm{O} 157$ yang bersifat patogenik (Kang and Fung, 1999).

\section{Metode Penelitian}

Penelitian ini bersifat eksploratif untuk mendeteksi keberadaan bakteri coliform pada minuman susu segar yang dijual oleh pedagang kaki lima di DIY. Pengambilan sampel dilakukan secara acak pada 12 lokasi pedagang kaki lima. Pengambilan sampel dilakukan seperti layaknya seorang pembeli kemudian segera dibawa ke laboratorium untuk dilakukan pengujian mikrobiologis.

\section{Enumerasi Langsung}

Enumerasi langsung dilakukan dengan memasukkan $50 \mathrm{ml}$ susu ke dalam $450 \mathrm{ml}$ pepton $1 \%$. Sampel digojog $150 \mathrm{rpm}$ pada suhu $37^{\circ} \mathrm{C}$ selama 10 menit. Selanjutnya dilakukan pengenceran dan ditumbuhkan pada medium CCA selama 24 jam pada suhu $37^{\circ} \mathrm{C}$ (Doyle and Schoeni, 1987; Turner, et al., 2000).

\section{Tahap Pengkayaan Culture)}

Tahap pengkayaan dilakukan dengan memasukkan $25 \mathrm{ml}$ sampel susu ke dalam 225 $\mathrm{ml}$ medium Vancomycin Tripticase Soy Broth (mVTSB) yang mengandung $40 \mathrm{mg} / \mathrm{L}$ vancomycin. Sampel diinkubasi dalam shaker incubator dengan agitasi $150 \mathrm{rpm}$ selama 16 jam pada suhu $37^{\circ} \mathrm{C}$. Selanjutnya dilakukan pengenceran dan ditumbuhkan pada medium CCA diinkubasi selama 48 jam pada suhu $37^{\circ} \mathrm{C}$ (Doyle and Schoeni, 1987; Tarr, et al., 1999; Turner, et al., 2000).

\section{Profil Koloni Coliform Pada Medium CCA}

Medium CCA adalah medium tunggal yang mengandung dua substrat kromogenik yaitu substrat untuk enzim B-Glucoronidase (5-bromo-4-chloro-3-indoxyl- $\beta$-D-glucoronide) dan $\beta$-Galactosidase (6-chloro-3-indoxyl- $\beta$-Dgalactosidase). Bakteri E.coli menunjukkan koloni dengan warna biru gelap, tetapi kelompok, Citrobacter, Enterobacter, Klebsiella memberikan warna koloni warna merah. Kelompok Salmonella, Shigella, dan Yersinia memberikan warna koloni biru terang (Turner, et al., 2000). Berdasarkan kenampakan 
warna koloni yang tumbuh dalam medium CCA tersebut akan diperoleh peta masingmasing populasi bakteri coliform yang mencemari susu. Jumlah koloni yang tumbuh dalam medium CCA dihitung sebagai unit pembentuk koloni (colony forming unit) dalam satu mililiter sampel (CFU/ml). Koloni biru gelap yang merupakan kandidat E.coli $\mathrm{O} 157$ diisolasi dan dilakukan uji identifikasi secara fisiologis.

\section{Identifikasi Kandidat E.coli 0157}

Isolat bakteri dari koloni warna biru gelap selanjutnya dilakukan uji IMViC dan uji ke medium Escherichia coli O157:H7 (EOH). Uji IMVIC yang dilakukan meliputi uji indol, methyl red (MR), voges-proskauer (VP) dan penggunaan sitrat (Benson, 1983; Cappuccino, 1983; AOAC, 1995; Atlas, 1997; Kang and Fung, 1999).

\section{Hasil dan Pembahasan}

Pada Tabel 1 ditunjukkan pola distribusi coliform hasil enumerasi langsung yang mencerminkan profil cemaran coliform. Pola distribusi ini diketahui berdasarkan kenampakan warna koloni yang tumbuh pada medium CCA (Turner, et al., 2000). Koloni berwarna biru gelap yang mewakili kelompok E.coli terdeteksi pada dua lokasi dari 12 lokasi pengambilan sampel dengan jumlah koloni sebesar $1,4 \times 10^{4}-2,8 \times 10^{4}$ (CFU/ml). Dengan demikian tidak semua lokasi menunjukkan terdapatnya cemaran E.coli. Koloni biru terang terdeteksi pada tujuh lokasi pengambilan sampel dengan tingkat cemaran sebesar $1 \times 10^{3}-2,1 \times 10^{6}(\mathrm{CFU} / \mathrm{ml})$. Koloni biru terang ini mewakili kelompok Salmonella, Shigella, dan Yersinia. Koloni merah terdeteksi pada delapan lokasi dengan tingkat cemaran sebesar $1 \times 0,10^{3}-1,2 \times 10^{7}(\mathrm{CFU} / \mathrm{ml})$. Koloni ini mewakili kelompok Citrobacter, Enterobacter, dan Klebsiella.

Standart mutu untuk susu mentah di beberapa negara tidak memberikan syarat khusus, akan tetapi standart mutu untuk susu pasteurisasi harus nol. Angka cemaran coliform dari data enumerasi di tiga lokasi (lokasi no: 10-12) penjualan bahan baku susu mentah berkisar $10^{5}$ $10^{7} \mathrm{CFU} / \mathrm{ml}$. Kualitas bahan baku susu mentah ternyata tidak baik sehingga ketika sampai $\mathrm{k}$ tangan pedagang kaki lima dengan pemasaka yang tidak sempurna maka masih terdeteks cemaran coliform. Pemasakan dengan car pasteurisasi pada suhu $60^{\circ} \mathrm{C}$ selama 30 meni hanya mampu menurunkan E.coli sejumlah 10 CFU/ml (Forsythe and Hayes, 1998; Muniesa, al., 1999). Dengan melihat hasil enumeras langsung maka perlu dilakukan berbagai upay untuk mengeleminasi populasi coliform. Par pedagang kaki lima perlu memperhatikan sanitas lingkungan mulai dari cara pencucian sampa pada penirisan gelas tanpa menggunakan kain la yang dipakai berulang-ulang. Saran in direkomendasikan mengingat buruknya sanitas lingkungan pada delapan lokasi penjualan sus segar.

Enrichment culture dalam mediun mVTSB dilakukan untuk mendeteksi koloni bir gelap yang tidak terdeteksi pada enumeras langsung. Hasil enumerasi menunjukkan bahw lima dari 10 lokasi terdeteksi koloni biru gelap tujuh dari 10 lokasi terdeteksi koloni biru terang sedangkan koloni merah terdeteksi pada semu lokasi (Tabel 2).

Tabel 1 dan 2 menggambarka perbandingan beberapa kelompok bakteri yan tidak muncul pada enumerasi langsung tetap muncul setelah dilakukan pengkayaan. Melalu tahap pengkayaan populasi bakteri coliform yan tidak terdeteksi dengan cara enumerasi langsun karena jumlahnya sedikit atau sel-sel denga aktivitas metabolik sangat lambat akan muncu. tumbuh dan memperbanyak sel dalam mediun mVTSB. Medium ini bersifat selektif untu menumbuhkan kelompok coliform. Bakteri gran positip akan terhambat pertumbuhannya denga penambahan bile salt no.3 sebanyak 1,5 g/l (Doyle and Schoeni, 1987; Tarr et al., 1999).

Melalui tahap pengkayaan diketahui das dua lokasi pengambilan sampel yang terdeteks koloni biru gelap meningkat menjadi terdeteks sebanyak tujuh lokasi. Koloni biru terang yan hanya terdeteksi pada tujuh lokasi pengambila sampel, setelah melalui tahap pengkayaa terdeteksi sebanyak sembilan lokasi. Sedangka koloni merah yang hanya terdeteksi pada delapa lokasi pengambilan sampel, setelah melalui taha pengkayaan terdeteksi di semua lokas pengambilan sampel. 
Caliform pada Minuman Susu Segar

Tabel 1. Pola distribusi coliform pada medium CCA hasil enumerasi langsung

\begin{tabular}{|c|c|c|c|c|}
\hline \multirow{2}{*}{$\begin{array}{l}\text { No } \\
\text { Sampel }\end{array}$} & \multicolumn{3}{|c|}{ Jumlah Koloni (CFU/ml) } & \multirow{2}{*}{$\begin{array}{c}\text { Jumlah } \\
\text { Coliform } \\
\text { (CFU/ml) } \\
\end{array}$} \\
\hline & Biru Gelap: E.coli & $\begin{array}{c}\text { Biru Terang: } \\
\text { Salmonella, Shigella, Yersinia }\end{array}$ & $\begin{array}{c}\text { Merah: Citrobacter, } \\
\text { Enterobacter, Klebsiella }\end{array}$ & \\
\hline 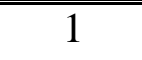 & $2,8.10^{4}$ & $1,1,0.10^{3}$ & $3,8.10^{4}$ & 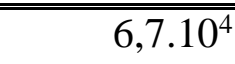 \\
\hline 2 & 0 & 0 & 0 & 0 \\
\hline 3 & 0 & 0 & 0 & 0 \\
\hline 4 & 0 & 0 & 0 & 0 \\
\hline 5 & 0 & 0 & $1,0.10^{3}$ & $1,0.10^{3}$ \\
\hline 6 & 0 & $1,0.10^{3}$ & 0 & $1,0.10^{3}$ \\
\hline 7 & $1,4.10^{4}$ & $8,0.10^{3}$ & $2,8.10^{4}$ & $5,0.10^{4}$ \\
\hline 8 & 0 & $2,0.10^{3}$ & $1,8.10^{4}$ & $2,0.10^{4}$ \\
\hline 9 & 0 & 0 & $4,4 \cdot 10^{6}$ & $4,4 \cdot 10^{6}$ \\
\hline 10 & 0 & $1,1.10^{5}$ & $5,5.10^{5}$ & $6,6.10^{5}$ \\
\hline 11 & 0 & $2,1.10^{6}$ & $1,0.10^{7}$ & $1,2.10^{7}$ \\
\hline 12 & 0 & $1,3 \cdot 10^{6}$ & $1,2.10^{7}$ & $1,3 \cdot 10^{7}$ \\
\hline
\end{tabular}

Tabel 2. Pola distribusi coliform pada medium CCA dari hasil enumerasi setelah melalui tahap pengkayaan.

\begin{tabular}{crrrr}
\hline \hline $\begin{array}{c}\text { No } \\
\text { Sampel }\end{array}$ & \multicolumn{2}{c}{ Jumlah Koloni (CFU/ml) } & Jumlah \\
\cline { 2 - 5 } & Biru Gelap: E.coli & $\begin{array}{c}\text { Biru Terang: } \\
\text { Salmonella, Shigella, Yersinia }\end{array}$ & $\begin{array}{c}\text { Merah: Citrobacter, } \\
\text { Enterobacter, Klebsiella }\end{array}$ & $\begin{array}{c}\text { Coliform } \\
\text { (CFU/ml) }\end{array}$ \\
\hline \hline 1 & $*$ & $1,3.10^{5}$ & $*$ & $*$ \\
2 & $1,3.10^{5}$ & 0 & $4,3.10^{5}$ & $6,9.10^{5}$ \\
3 & 0 & 0 & $3,7.10^{5}$ & $3,7.10^{5}$ \\
4 & 0 & 0 & $1,3.10^{6}$ & $1,3.10^{6}$ \\
5 & 0 & $8,0.10^{6}$ & $3,6.10^{5}$ & $3,6.10^{5}$ \\
6 & $3,9.10^{6}$ & $*$ & $6,5.10^{6}$ & $1,8.10^{7}$ \\
7 & $*$ & $1,3.10^{4}$ & $*$ & $*$ \\
8 & $2,0.10^{3}$ & $1,7.10^{4}$ & $9,1.10^{4}$ & $1,1.10^{5}$ \\
9 & 0 & $3,0.10^{15}$ & $2,4.10^{5}$ & $2,6.10^{5}$ \\
10 & $1,0.10^{15}$ & $1,0.10^{12}$ & $9,7.10^{16}$ & $1,0.10^{17}$ \\
11 & $1,0.10^{12}$ & $1,0.10^{15}$ & $2,2.10^{13}$ & $2,4.10^{13}$ \\
12 & 0 & $1,3.10^{17}$ & $1,3.10^{17}$ \\
\hline \hline
\end{tabular}

Keterangan: * tidak dilakukan pengujian karena hasil enumerasi langsung sudah terdeteksi koloni biru gelap.

Berdasarkan kenampakan warna koloni yang tumbuh pada medium CCA baik dari hasil enumerasi langsung maupun setelah melalui tahap pengkayaan dapat diketahui bahwa kelompok coliform merah menduduki peringkat tertinggi, disusul oleh kelompok biru terang, dan biru gelap. Kenampakan warna koloni yang berbeda-beda dari anggota coliform pada medium CCA disebabkan oleh perbedaan kemampuan metabolik menggunakan substrat untuk enzim $\beta-$ glucoronidase yaitu 5-bromo-4-chloro-3-indoxyl$\beta$ - $D$-glucoronida dan substrat untuk enzim $\beta$ gallactosidase yaitu 6-chloro-3-indoxyl- $\beta$-Dgalactocida. Koloni E.coli berwarna biru gelap sampai violet sebab $96 \%$ E.coli dapat menggunakan substrat untuk enzim $\beta$ galactosidase dan $\beta$-glucoronidase. Koloni Citrobacter, Enterobacter, dan Klebsiella berwarna merah karena dapat menggunakan substrat untuk enzim ß-galactosidase tetapi tidak dapat menggunakan substrat untuk enzim $\beta$ glucoronidase. Sebaliknya kelompok Salmonella, Shigella, dan Yersinia tidak dapat menggunakan substrat enzim $\beta$-galactosidase tetapi dapat menggunakan substrat enzim $\beta$-glucoronidase sehingga berwarna biru terang (Turner, et al., 2000).

Untuk memastikan apakah koloni biru gelap yang tumbuh dari hasil enumerasi bersifat patogenik, dilanjutkan dengan serangkaian uji fisiologis dan uji pada medium $\mathrm{EOH}$. Uji fisiologis yang dilakukan meliputi indol, laktosa, methyl red, voges proskauer, dan penggunaan sitrat (Tabel 3). 
Tabel 3. Hasil Uji Fisiologis Isolat Biru Gelap

\begin{tabular}{|c|c|c|c|c|c|c|c|}
\hline \multirow[t]{2}{*}{ Isolat dari Sampel } & \multirow[t]{2}{*}{ EIsolat } & \multicolumn{5}{|c|}{ Uji Fisiologis } & \multirow[t]{2}{*}{ Hasil Identifikasi } \\
\hline & & Indol & Sitrat & Laktosa & $M R$ & $V P$ & \\
\hline 1 & 1 & + & - & + & + & - & Eschrichia coli \\
\hline 2 & 5 & + & - & + & + & - & E.coli \\
\hline 6 & 3 & + & - & + & + & - & E.coli \\
\hline 7 & 1 & + & - & + & + & - & E.coli \\
\hline 8 & 2 & + & - & + & + & - & E.coli \\
\hline 10 & 3 & + & - & + & + & - & E.coli \\
\hline 11 & 3 & + & - & + & + & - & E.coli \\
\hline
\end{tabular}

Berdasarkan hasil identifikasi, diketahui bahwa koloni biru gelap merupakan E.coli. Untuk mendeteksi keberadaan E.coli O157 dilakukan pengujian kemampuan menggunakan sorbitol dalam medium EOH. Isolat yang tidak dapat menggunakan sorbitol tampak berwarna merah. Pada medium EOH isolat E.coli menyebabkan medium berwarna kuning. Warna kuning pada medium EOH disebabkan E.coli mampu memfermentasikan sorbitol menghasilkan asam. Produk asam akan menyebabkan penurunan $\mathrm{pH}$ medium sehingga indikator phenol red berubah menjadi warna kuning. Warna kuning pada medium EOH ini dipakai sebagai penanda untuk membedakan isolat E.coli dan E.coli O157 (Kang and Fung, 1999). Isolat E.coli O157 jika ditumbuhkan pada medium EOH akan tetap berwarna merah karena tidak mampu menggunakan sorbitol sehingga tidak membentuk produk asam. Semua isolat yang berasal dari sampel minuman susu segar yang dijual pedagang kaki lima di 12 lokasi pengambilan sampel mampu menggunakan sorbitol. Walaupun tidak diperoleh isolat yang berpotensi patogenik, perlu dilakukan upaya perbaikan sanitasi lingkungan mengingat angka kontaminasi coliform yang cukup tinggi.

\section{Kesimpulan dan Saran}

Tingkat cemaran coliform pada minuman susu segar yang dijual pedagang kaki lima berkisar $1,0 \times 10^{3}-1,3 \times 10^{7}$ (CFU/ml). Cemaran coliform didominasi oleh kelompok Citrobacter, Enterobacter, dan Klebsiella $\left(1,0 \times 10^{3}-1,2 \times 10^{7} \mathrm{CFU} / \mathrm{ml}\right)$, kemudian disusul oleh kelompok Shigella, Salmonella, Yersinia $\left(1,0 \times 10^{3}-2,1 \times 10^{6} \mathrm{CFU} / \mathrm{ml}\right)$, dan E.col $\left(1,4 \times 10^{4}-2,8 \times 10^{4} \mathrm{CFU} / \mathrm{ml}\right)$. Isolat biru gela yang dicurigai sebagai kandidat E.coli $\mathrm{O} 15$ tidak mampu memfermentasi sorbitol, sehingg pada sampel minuman susu segar yang ditelit tidak terdapat E.coli $\mathrm{O} 157$ yang bersifa patogenik.

Walaupun hasil identifikasi tidal diperoleh isolat E.coli patogenik, bagi par pedagang minuman susu segar perl meningkatkan kebersihan lingkungan untu menekan tingginya cemaran coliform.

\section{Daftar Pustaka}

Adnan, 1984. Kimia dan Teknologi Pengolahan Air Sust Andy Offset, Yogyakarta.

AOAC. 1995. Food and Drug Administratior Bacteriological Analytical Manual. $8^{\text {th }}$ ed, $\mathrm{pr}$ 5.01-5.19. AOAC International, USA.

Atlas, R.M. 1997. Principles of Microbiology. $1^{\text {nd }} \mathrm{ed} . \mathrm{pt}$ 976-985.Win.C.Brown Publishing, Iowa.

Benson, H.J. 1983. Microbiological Application Laboratory Manual in General Microbiolog. pp. 105. Wm.C.Brown Publishing, Iowa.

Borczyk, A.A., Karmali, M.A., Lior, H. and Duncar L.M.C. 1987. Bovine Reservoir fo Verotoxin-Producing Escherichia coli Infants and Toddlers in Czechoslovakic Infection 18: 352-355.

Brock, T.D. 1999. Biology of Microorganism. Prentice Hall, Inc. Englewood Cluffs, New Jersey.

Budiarso, T.Y. dan Amarantini, C. 2002. Prevalen Cemaran Coliform dalam Susu Segar pad Kelompok Peternak di Kabupaten Slemar National Colloquium A Critical Look on Foo Research in Indonesia. ISBN: 979-97 002-C 5. PF-9.

Cappucino, J.G. and Sherman, N. 1983. Microbiology Laboratory Manual. Addison-Wesle Publishing, California. 


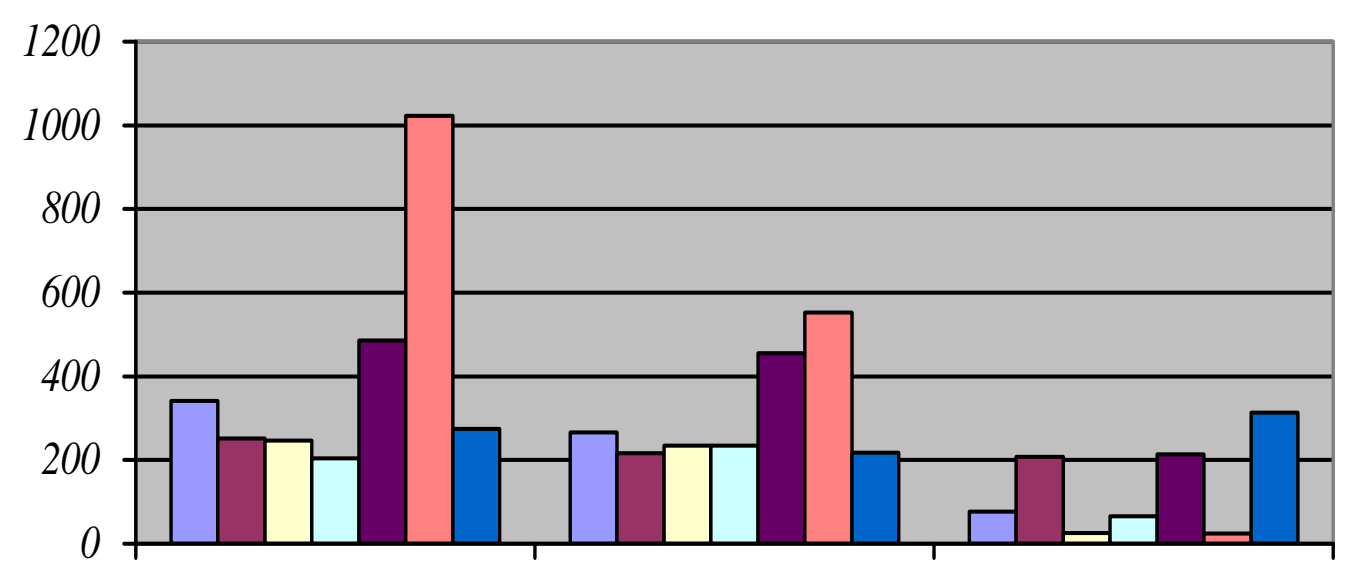

Oktober

November

Desember
$\square$ Argobuccinum pustulosum
$\square$ Conus lividus
$\square$ Cypraea annettae
$\square$ Cypraea annulus
$\square$ Cypraea moneta
$\square$ Pyrene testudinaria
$\square$ Rhinoclavis bituberculata Susu Segar

Doyle, M.P. and Cliver, D.O. 1990. Foodborne Diseases. Academic Press, Inc. San Diego.

Doyle, M.P. and Schoeni, J.L. 1987. Isolation of Escherichia coli O157:H7 from Retail Fresh Meats and Poultry. Applied Environmental Microbiology 53 : 2394-2396.

Forsythe, S.J. and Hayes, P.R. 1998. Food Hygiene,

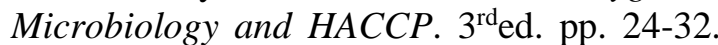
Aspen Publishing Inc. Gaithersburg, Maryland.

Harding, F. 1999. Milk Quality. Aspen Publishers, Inc. Geithersburg, Maryland.

Jay, J.M. 1978. Modern Food Microbiology. $2^{\text {nd }}$ ed. Van Nostrand Reinhold Company, New York.

Kang, D.H. and Fung, D.Y.C 1999. Development of a Medium for Differentiation between Escherichia coli and Escherichia coli O157:H7. Journal of Food Protection 62 (4):313-317.

Muniesa, M., Lucena, F. and Jofre, J. 1999. Comparative Survival of Free Shiga Toxin-2 Encoding Phages and Escherichia coli Strains Outside the Gut. Applied Environmental Microbiology 65: 5615-5618
Padhe, N.V. and Doyle, M.P. 1991. Rapid Procedure for Detecting Enterohemorrhagic Escherichia coli $\mathrm{O} 157: \mathrm{H} 7$ in Food. Applied Environmental Microbiology. 57:2693-2698.

Ray, B. 1996. Fundamental Food Microbiology. CRC Press, Boca Raton.

Steinhart, C.E., Doyle, M.E. and Cochrane, B.A. 1996. Food Savety. Marcel Dekker, Inc. Madison Avenue, New York.

Tarr, P.I., Tran, N.T. and Wilson, R.A 1999. Escherichia coli O157:H7 in Retail Ground Beef in Seattle: Result of One-Year Prospective Study. Journal of Food Protection 62:133139.

Todar, K. 1997. Bacteriology 330 Lecture Topics: Pathogenic Escherichia coli. Departement of Bacteriology. University of Wisconsin.

Turner, K.M., Restaino, L. and Frampton, E.W. 2000. Efficacy of Chromocult Coliform Agar for Coliform and Escherichia coli Detection in Foods. Journal of Food Protection 63 (4): 539-541. 